This is an Accepted Manuscript of an article published by Sage in the Journal of Adult and Continuing Education on $4 / 5 / 17$.

To cite this article: Palesy, D (2017): Developing manual handling skills in relative social isolation: A case study of Australian home care workers, Journal of Adult and Continuing Education, DOI https://doi.org/10.1177/1477971417707220

\title{
Developing manual handling skills in relative social isolation: \\ A case study of Australian home care workers
}

\begin{abstract}
This paper elaborates how home care workers (HCWs) develop skills in their workplaces after only brief classroom manual handling training and suggests how this development may be supported in situations of relative social isolation. A qualitative approach was adopted for this inquiry, in which new HCWs were directly observed and interviewed in their workplaces at two points over a 12-week pre-determined training trajectory. When developing skills in their socially isolated workplaces, these workers followed a pathway that differs from traditional accounts. They developed procedural capacities first, rendered this knowledge and skill into principled understandings, and then adapted these understandings to become skillful in a range of other tasks. Moreover, these workers placed high value on sociality in developing their skills. Consequently, a training format which focuses on the development of procedural knowledge and provides opportunities for shared practice is most important for learning in circumstances of relative social isolation.
\end{abstract}

\section{Introduction}

This paper reports the findings from a study that evaluated how Australian home care workers (HCWs) develop manual handling skills in their workplaces over 12 weeks, after only brief classroom training. As home care work is carried out in the privacy of clients' homes, these workers are socially (or professionally) isolated, in that they do not have the 
close support and guidance of more experienced colleagues (Cantillon, 2016). Consequently, HCWs enter these workplaces as novices and are expected to very quickly demonstrate the attributes of experts, completing challenging and complex tasks without professional supervision or support.

Conceptually, this paper is concerned with understanding the bases for developing skills in circumstances of relative social isolation. A constructivist approach to describing, explaining and predicting how HCWs develop and enact the requirements for their roles is adopted for this inquiry. The essential premise of this approach is that learners play a central and highly active role in the construction and enactment of their knowledge, that individual and socio-cultural experiences are important in the knowledge construction process, and that this knowledge created will be represented by the learner in diverse ways (Fosnot, 2013; Gergen, 1994; Valsiner, 2000; Von Glasersfeld, 1984; Vygotsky, 1978). Moreover, considerations of both the social and physical world (i.e., external factors) and individual agency (i.e., internal factors), and the particular relations between them may provide some clues to better understand how skills develop in relative social isolation (Billett, 2001; Valsiner, 1994). Developing skills in safe manual handling is helpfully illustrative here of what both these perspectives can contribute, and of the complex relations between them.

Procedurally, understanding how HCWs develop skills in their clients' private homes is critical for the quality of support they provide to their clients, and also for their own health and wellbeing. Therefore, in addition to understanding how these workers learn and enact skills after only brief classroom training and in the absence of direct supervision and support, this paper also proposes some recommendations for curriculum and training provisions that may be appropriate in these circumstances. This paper focuses only on manual handling skills development of a small group of workers in one home care organisation. However, it is anticipated that the recommendations in this paper may extend to other elements of training 
for the HCW role, and indeed, to many other groups of workers who conduct their practice without direct supervision or support.

\section{Manual handling skills: A major goal for safe and healthy HCWs and clients}

The home care sector in Australia is rapidly expanding, for a range of reasons that include older adults and people with disabilities and chronic illnesses increasingly opting to remain in their own homes for care rather than move to residential care facilities (Health \& Community Services Workforce Council, 2012). Home care work assists such people to live independently for as long as possible in their own homes and communities (Keleher, 2003). Manual handling comprises a major component of home care work, including physical activities such as assisting people to bathe, toilet and mobilise, in addition to cleaning, shopping and other domestic duties. In essence, home care work represents a diverse set of activities that require skills development in different ways, purposes and circumstances, all in the relative privacy of clients' homes.

While the importance of an appropriately skilled home care workforce is recognised (Australian Skills Quality Authority, 2013; Martin \& Healy, 2010), job training and preparation frequently fail to prepare HCWs for the physical and emotional challenges of their role (Mott, Chau \& Chan, 2007; Stone, Sutton, Bryant, Adams \& Squillace, 2013). These challenges potentially impact on recruitment, training and retention of staff (Stone et al., 2013) and cause high rates of musculoskeletal (predominantly back) injuries (Faucett, Kang \& Newcomer, 2013; Markannen et al., 2014).

Training to prepare $\mathrm{HCW}$ s for their roles tends to be improvised, varying in format and content (Aylward, Stolee, Keat \& Johncox, 2003; Baldock \& Mulligan, 2000; Bernoth, 
2009) and is often followed by negligible support and supervision in the workplace (Aylward et al., 2003; Palesy, 2016). Clients, too, may experience serious health implications from inconsistent training of HCWs, with injuries such as bruising, skin tears, pressure sores and emotional trauma frequently reported as a consequence of poor manual handling ("Nursing home found in breach of act over accident with a hoist", 2008; Tuohy-Main, 1997).

Consequently, facilitating the development of HCWs' manual handling skills is essential, because this can potentially reduce musculoskeletal injury rates, staff turnover and costs to organisations in recruiting, orientating and training new staff, which may ultimately lead to safer and better quality support for clients (Palesy, 2015).

\section{Skills for safe practice}

Fitts and Posner (1967) proposed a three-phase model of skill acquisition that consists of a cognitive phase, an associative phase and an autonomous phase. In the cognitive phase, the learner forms a mental representation of the required action to execute the skill. This representation is physically rehearsed in the associative phase, as the basis of the skill is established and the skill is refined and further developed. In the autonomous phase, after much practice, the learner has mastered the skill and little conscious effort is required for its performance. This mastery can then be used to apply the skill to other, more complex situations (Fitts \& Posner, 1967).

Anderson (1982) later related this three-phase model to an early version of his Adaptive Control of Thought (ACT) theory (cited in Tenison, Fincham \& Anderson, 2016). In this theory of skill acquisition, workers will consciously retrieve their domain-specific conceptual knowledge (i.e., concepts, facts, assertions, propositions), or knowledge 'that' (Ryle, 1949), in an effort to perform the required skill. However, as they move towards more autonomous stages of skill acquisition, workers will rely less on this type of knowledge and 
more on the advancement of their procedural (i.e., techniques, skills, procedures) knowledge, or knowledge 'how' (Ryle, 1949) to develop expertise (Anderson, 1982). As these learners establish links and associations amongst concepts, their depth of understanding about their role increases and they are more likely to be able to solve complex workplace problems (Billett, 2013).

Only two sets of workers are distinguished by Cornford (1996): more experienced workers (i.e., competent, proficient and expert) and inexperienced (i.e., novices and advanced beginners). He defines novices or advanced beginners as those who are new to a particular field of work and who have not yet fully developed the range of skills required for satisfactory work performance, and experts as those who can learn and work autonomously, consistently demonstrating exceptional knowledge, skill and problem-solving.

These (and other) accounts of skills development suggest structured sequences, where learners first develop their propositional before procedural knowledge (e.g., Anderson, 1982, 1993; Fitts \& Posner, 1967; Glaser, 1984) or move from 'novice' to 'expert' (e.g., Benner, 2004; Cornford, 1996; Stevenson, 1994). However, others (e.g., Billett, 2001; Ericsson, 2004; Wilkesmann \& Wilkesmann, 2011) argue that there is no particular sequence of proficiency and in fact, expertise is situation-specific. That is, a skilful worker in one situation may be considered quite inept in another, because they may lack the kinds of knowledge required to be effective in that setting. This effectiveness may depend largely on the circumstances of work which, beyond generic principles required for practice, are unlikely to be identical in all situations. This may be true of the home care workplace. For example, a HCW may be an expert in manually handling people with challenging behavioural issues (e.g., encouraging the person to walk, using specific hand grasps and verbal cues to handle an uncooperative or resistive client), yet the same person may be a novice in using a mechanical hoist to move a person with a physical disability from the floor. 
Nevertheless, whether skills develop in sequence or otherwise, this type of learning is likely to be person-dependent. Becoming skilful in home care work may require some kind of negotiation by the individual between their cognitive and social experiences (Cobb, 1998; Salomon, 1997) and, therefore, is likely to be personally and culturally unique (Valsiner, 2000). Moreover, it may be the individual learner who exercises their professional agency, deciding what knowledge and skills are worth learning, and the level of engagement in their development (Eteläpelto, Vähäsantanen, Hökkä \& Paloniemi, 2013; Goodnow, 1990). So, when working in relative social isolation, there may be personal and social contributions to skills development.

The idea that an individual's pathway to expertise involves a deepening process of participation in a community associated with practice has gained significant ground in recent decades (Brown, Collins, \& Duguid, 1989; Gherardi, 2009; Hughes, Jewson \& Unwin, 2013; Lave \& Wenger, 1991; Rogoff \& Lave, 1984). Communities of practice are groups of people who engage in a process of collected learning in a shared domain of human endeavour (e.g., a tribe learning to survive, an online discussion forum, workers on a factory floor, scientists in a laboratory (Lave \& Wenger, 1991), each with a particular set of norms and practices known as the culture of practice (Brown et al., 1989). It is through the process of sharing information and experiences with the group that the members learn from each other and have an opportunity to develop and continually evolve, both personally and professionally (Cantillon, 2016; Lave \& Wenger, 1991). In addition, expertise is associated with identity formation and transformation, as learners move from peripheral to full participation and acceptance in a community of practice (Stevenson, 1994). So, skills development within this framework is conceptualised as the socio-cultural construction and organisation of knowledge, is transformed by the particular practices of a community (Billett, 2001), and is characterised by full participation in a community of practice (Lave \& Wenger, 1991). These concepts (i.e., 
structured sequences, context-specific and person-dependent development, formation of worker identities) pose challenges for managers and educators in the home care sector. That is, how best do they assist their HCWs to become skilful in a relatively short timeframe, after only brief classroom training and with negligible supervision or support in the workplace?

\section{The 12-week training trajectory}

A practical study which explored the existing manual handling training situation for home care workers (Palesy, 2015), proposed a training trajectory which may support individuals who are required to develop skills without direct supervision or support. This trajectory was enacted in four phases: (a) an initial classroom training session in which trainees were supported to develop a disposition for support work, learn important concepts and routine manual handling tasks (e.g., rolling a client in bed, pushing a wheelchair, using a mechanical hoist); (b) consolidation and extension of this learning with guidance from 'more skilful others' (e.g., preceptor, service coordinator, knowledgeable client and/or family member) in the workplace upon request; (c) a return to the classroom to provide discussion opportunities for new workers to build on concepts, procedures and dispositions; and (d) working independently with a client but with access to 'more skilful others' as required. The methodological approach selected to appraise HCWs' skills development at various points in this trajectory is discussed in the next section.

\section{Method}

The inquiry adopted a case study approach to first, understand the actual, complex and current problem of how manual handling skills develop and then, to offer solutions for improving training practices (Merriam, 2014, Yin, 2009). The case comprised one Australian home care organisation whose staff provide a range of lifestyle supports to clients in their 
private homes, including manual handling activities such as pushing wheelchairs, repositioning in bed, bathing and general housekeeping.

\section{Informant selection}

Research in the home care sector is challenged by low staff retention and high turnover of HCWs (Radford, Shacklock \& Bradley, 2015), and issues around gaining access to clients' private homes for observation. Therefore, informant selection was non-random and based on convenience. One class of 20 newly recruited HCWs were invited to participate in the study, and of these it was hoped that ten would agree to take part. However, only seven expressed an interest and remained committed to the 12-week study period. These informants comprised three males and four females of various ages, cultural backgrounds and life (including previous education and work) experiences. So, these diversities among the informants may have contributed to the richness of qualitative data obtained during the study. Moreover, this rich data may also be attributed to the generosity and enthusiasm of the informants who participated in the project, including their willingness to be observed and their engagement in the interviews. For the purposes of confidentiality and de-identification, all informants (and the organisation) were assigned pseudonyms.

\section{Data collection}

Qualitative data were obtained in the form of direct observations and semi-structured interviews that aimed to capture how new HCWs were developing manual handling skills in their workplaces. The data were collected from each informant at two points (i.e., at 4 and12 weeks after initial classroom training). Direct observation data were collected first and semistructured interviews followed immediately afterwards, so that interview questions substantiating already established facts or observations could guide some of the questioning.

For the observations, informants were observed performing two core manual handling tasks: (a) pushing a client in their wheelchair; and (b) using a hoist to transfer a client from 
their bed to their wheelchair. These tasks were observed against four pre-determined criteria that were considered fundamental to successful manual handling: (a) planning and preparing for each task; (b) establishing a balanced body position before attempting to handle the client, and keeping the load close to the body; (c) using the pelvis to power the movement rather than overworking the muscles of the back and shoulders; and (d) conscious recruitment of the core stabiliser muscles when performing manual handling tasks (Varcin-Coad, 2003). These criteria formed the basis of the checklists used by the researcher for directly observing and recording informants' manual handling skilfulness. The observations were conducted with the researcher as a participant- observer (Yin, 2009). Given the intimacy of clients' private homes, informants were aware that they were being observed; however, they were unaware of the specific details of the observation. This type of observation was considered appropriate because it has been previously successful in everyday settings (Yin, 2009), and by working alongside the informants, they may have been less inclined to display their best behaviour. Indeed, it appeared that informants were relaxed and comfortable during the observation.

Interview questions at both points aimed to identify how informants were developing manual handling skills at various points of the training trajectory. Interviews followed a predetermined set of questions, while still remaining fluid and spontaneous. For example, at both data collection points, informants were asked to identify manual handling problems they had encountered in their workplaces, and to describe the ways in which they had selected and enacted solutions for these problems. Other questions emerged from the direct observations of informants, for example: "I notice that you [positive or negative observation in relation to a manual handling technique]. What made you do it this way"? A combination of both audio recording and written notes was used to record the interview data. 


\section{Data reduction and analysis}

Inductive reasoning principles were used to reduce and analyse the data, by searching for patterns, categories or themes in relation to skills development and the implemented training trajectory (Blaikie, 2009; Thomas, 2006). These data were read, specific segments of information were identified, summarised and arranged in general categories, and were then edited to reduce overlap and redundancy (Thomas, 2006). Observation checklists were coded according to the four pre-determined criteria. Data were searched systematically for particular words, phrases, behavioural patterns, views and accounts that were repeated or conspicuous (Bogdan \& Biklen, 2007). The aim here was to derive a set of propositions from the data about the development of HCWs' manual handling skills at various points of the training trajectory. So, it was anticipated that analysis of data derived from multiple sources and at two different points provides richness of data and validity to the findings of the study.

\section{Study limitations}

Several limitations are acknowledged in this unique and small-scale study, which suggest that the findings should be viewed as tentative and exploratory. Firstly, in view of high turnover of HCWs, and gaining access to clients' homes for data collection, only a small number of informants were recruited for study. However, because qualitative research methods are resource-intensive, Blaikie (2009) supports smaller samples in these instances. Trialing and honing of tools prior to actual data collection ensured that comprehensive data were collected from each informant.

Researcher bias may be a study limitation. This data were collected by a researcher who, as a registered nurse and manual handling educator is very familiar with the criteria for manual handling competence and with extensive experience in supporting clients in home care settings. Moreover, the data were collected in natural settings (i.e., clients' private homes), where physical, social and interpersonal interactions may change at any given 
moment, and there is the potential for informants to modify their behaviour when being observed or interviewed. So, the findings here represent only one perspective, and may only be replicated by researchers who assume comparable roles. Nonetheless, LeCompte and Goetz (1982) suggest that while findings generated from natural settings by researchers in specific social positions may be limited, they are still legitimate. The conclusions drawn here represent one reality - a data snapshot which, when combined with the research of others in different social positions and in different settings, contribute to a holistic picture of the issue (LeCompte \& Goetz, 1982).

Finally, as each case study has many unique aspects, another limitation of this study may be its applicability to other workplace learning situations (Wiersma, 2009). The Australian home care sector workforce is predominantly female (AIHW, 2013), yet four of the seven informants recruited for the study were male. These informants however, were the only ones who volunteered to participate and who remained committed to the 12 -week period. The case for study was selected because its features were representative of many home care providers in Australia in terms of manual handling tasks carried out. The question is, however, whether the study findings are generalisable to a range of circumstances. To paraphrase Stenhouse (1988), readers will have to judge for themselves the applicability of this case to their own situation. This may be assisted, however, by clearly defining the boundaries of the case upfront, along with providing clear guides for data collection. In this way, it is hoped that this study may be easily replicated.

\section{Ethical considerations}

Ethical approval was granted prior to conducting the research. Information packages were provided and consent was obtained from the home care organisation, all informants and their clients prior to collecting data for the study. 


\section{Findings}

Semi-structured interviews and observations yielded data about how HCWs developed manual handling skills in their socially-isolated workplaces. This data is presented in two tables. Table 1 provides an overview of how each informant engaged with the learning supports provided as part of the training trajectory, along with data supporting their manual handling skills competency and sample interview responses. Table 2 reports how the informants' manual handling skills developed over each phase of the training trajectory. First, in Table 1, the left-hand column identifies the informant. The second left column provides a brief summary of each specific informant's use of available learning supports to enact safe manual handling techniques. The next column comments on whether or not each informant met the observable criteria for successful manual handling performance at four and 12 weeks post initial classroom training. The final, right-hand column provides some sample interview responses to substantiate informants' use of learning supports in achieving manual handling skilfulness. 
Table 1. Engagement with the Training Trajectory

\section{Use of learning supports}

Main form of support used was the group work in both initial and refresher classroom sessions (i.e., up

to 8 weeks post initial training). Also referred to the classroom training handout. Liked having access to a range of learning supports.

Used 'more skilful others' as a support in all four

phases of the framework (i.e., up to 8 weeks and

beyond). Considered the group work in the refresher

training to be valuable. Did not refer to written materials at all.

Used the group work in both classroom training

a sessions as a form of learning support. Written

materials referred to regularly in the first 8 weeks, but not thereafter. Did not use 'more skilful others' at all.

Used 'more skilful others' in the first 8 weeks, but not thereafter. Considered the group work in the

refresher training to be valuable. Did not refer to

written materials at all, but did report the value of all provided learning supports

Reported the value of group and practical activities in

- the initial classroom training; called on the preceptor occasionally in the first 8 weeks.

Considered 'more skilful others' as a useful form of

support in the first 8 weeks, but not thereafter.

Considered the group work in the refresher training to be valuable. Did not refer to written materials at all.

Considered the classroom activities in initial and

v refresher the most useful form of learning support.

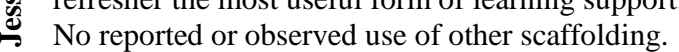

Skills competency

Met all observable criteria at 4 and 12 week

Met all observable criteria at 4 and 12 weeks

Met all observable criteria at 4 and 12 weeks

Met all observable criteria at 4 and 12 weeks

Met all observable criteria at 4 and 12 weeks

Met all observable criteria at 4 and 12 weeks

Met all observable criteria at 4 and 12 weeks

\section{Sample interview responses}

"[I] went through each activity at a reasonable pace, but at the same time receive[d] input from others".

"I made notes... and ... read over it a few times, just to check that I'm doing the right thing"

"It's good to have a safety net"

"I liked seeing [the service coordinator] in the classroom and out here [in the workplace]...it helps..."

"I couldn't believe how much I learned...I thought [I had] come a long way [in 8 weeks]"

“... I related [the classroom activities] to the job I was doing with my client...It's what saved me that time, saved the pair of us" (on successfully preventing a client from falling out of their wheelchair)

"I used...the photos and all the steps for some of the transfers, [for] the harder [tasks]"

"I... [used the workplace preceptor as] my phone-a-friend strategy...to bounce ideas off...make sure I was doing the right thing"

"It helps to get up and move around [in the classroom]...practice some things...have fun basically"

"I thought that in the beginning that maybe I wouldn't need [the preceptor]...but just someone in the house every now and then...help[ed]"

"I like seeing [the preceptor] out here, even if we don't need her"

"It helps to get together [in refresher] training, sit around and nut things out"

"Learning the basics [in the initial classroom training], the body positioning, learning the importance of it ... practicing ... really helpful"

"The more you practice [in the classroom] the more it will sink in" 
Table 1 indicates that most of the supports were used in the first eight weeks of learning the requirements for the $\mathrm{HCW}$ role. During initial classroom training, most use was made of the group work and practical activities in the classroom as a means of developing manual handling skill, while in the eight weeks on-the-job after initial classroom training, most use was made of the 'more skilful others'. Upon return to the classroom for refresher training at eight weeks, six of the seven informants reported or were directly observed to engage with the classroom activities. Beyond this classroom refresher at eight weeks, only one informant reported or was observed to use the available learning supports to enact safe manual handling practices in their clients' homes. Noteworthy in Table 1 also, is that written materials, accessible in all four phases of the training trajectory, were the least used form of learning support. So, HCWs seemed to place more value on sociality (i.e., engagement with experts, peers in the classroom) as a way of developing their skilfulness.

All HCW informants met the observable criteria for manual handling competency at both four and 12 weeks post initial classroom training. Yet, they each followed a personally unique pathway to reach this level of proficiency. No two informants engaged with the training trajectory in the same way. Instead, they were selective about the supports used to develop skilfulness in the absence of expert guidance: what was utilised by one worker was considered less important by another and some required less support than others.

Consequently, skills development appears to be person-dependent when learning in circumstances of relative social isolation.

Table 2 further demonstrates the personally unique pathway that these informants take in developing their manual handling skills, at each phase of the training trajectory. The lefthand column reiterates each phase of the trajectory. The second left column provides a description and summary of what appears to have occurred by way of skills development during that phase, and the next column locates this description within a particular learning 
focus, that is, either conceptual or procedural development. The right-hand column provides sample responses from informants to support their personally unique skills development. 
Table 2. Phases of Skills Development for HCWs

\begin{tabular}{|c|c|c|c|}
\hline Skills phase & Skills development & Learning focus & Sample interview responses \\
\hline \multirow[t]{2}{*}{$\begin{array}{l}\text { One: } 0 \text { weeks } \\
\text { Initial classroom training }\end{array}$} & $\begin{array}{l}\text { Informants observed in the classroom to be } \\
\text { replicating two key manual handling procedures } \\
\text { (i.e., pushing a client in wheelchair, using a } \\
\text { mechanical hoist). }\end{array}$ & \multirow[t]{2}{*}{ Procedural } & $\begin{array}{l}\text { "....it's the body stuff that stays with you.... I think it all comes down to } \\
\text { how you position yourself ... your body. Once you get that then you } \\
\text { can do anything". (Pete, trainee) }\end{array}$ \\
\hline & $\begin{array}{l}\text { Concern appears to be more about performing the } \\
\text { tasks (i.e., the practical component of the training } \\
\text { session) than the concepts taught in the didactic } \\
\text { component of the classroom training }\end{array}$ & & $\begin{array}{l}\text { "[it was helpful] to get up and move around [in the classroom], practice } \\
\text { some things..." (Nat, trainee) }\end{array}$ \\
\hline \multirow{3}{*}{$\begin{array}{l}\text { Two: } \mathbf{0} \text { - } 8 \text { weeks } \\
\text { Working independently } \\
\text { in clients' homes but } \\
\text { with access to 'more } \\
\text { skilful others' and other } \\
\text { learning supports }\end{array}$} & $\begin{array}{l}\text { Enacting/practising a range of procedural skills } \\
\text { beyond those rehearsed in the classroom - e.g., } \\
\text { managing a client fall, domestic duties }\end{array}$ & \multirow[t]{3}{*}{ Procedural } & \multirow{2}{*}{$\begin{array}{l}\text { "... I don't even have to think about it ... I never thought I'd be able to } \\
\text { do [a standing transfer] properly you know, but everything just happens } \\
\text { automatically..." (Jess, trainee, on successfully supporting a client } \\
\text { during a seizure) }\end{array}$} \\
\hline & \multirow[t]{2}{*}{$\begin{array}{l}\text { More references are made by informants to the } \\
\text { development of their procedural knowledge }\end{array}$} & & \\
\hline & & & $\begin{array}{l}\text { "...the body stuff, I still [practice] it...to vacuum and mop" (Barb, } \\
\text { trainee) }\end{array}$ \\
\hline \multirow[t]{2}{*}{$\begin{array}{l}\text { Three: } 8 \text { weeks } \\
\text { Refresher classroom } \\
\text { training }\end{array}$} & \multirow[t]{2}{*}{$\begin{array}{l}\text { Observed to be applying principled understandings } \\
\text { of manual handling concepts to non-routine manual } \\
\text { handling tasks }\end{array}$} & \multirow[t]{2}{*}{ Conceptual } & $\begin{array}{l}\text { "... locking in the basics, for sure... then...build on them ...It's what } \\
\text { saved me that time, saved the pair of us" (Dan, trainee, on successfully } \\
\text { preventing a client from falling out of their wheelchair) }\end{array}$ \\
\hline & & & $\begin{array}{l}\text { "I think [the trainees in the refresher session are]...starting to think } \\
\text { critically about manual handling...rather than going through the } \\
\text { motions" (Sue, manual handling trainer) }\end{array}$ \\
\hline \multirow{3}{*}{$\begin{array}{l}\text { Four: } 8 \text { weeks and } \\
\text { beyond } \\
\text { Working independently } \\
\text { with access to learning } \\
\text { supports as required }\end{array}$} & $\begin{array}{l}\text { Successfully performing manual tasks } \\
\text { independently }\end{array}$ & \multirow[t]{3}{*}{ Conceptual } & \multirow{2}{*}{$\begin{array}{l}\text { "I think the more you actually think about how [the manual handling } \\
\text { concepts] appl[y] to other aspects of your life, the more you practise } \\
\text { and then it's definitely going to sink in" (Nat, trainee, on applying } \\
\text { classroom-taught manual handling concepts to riding a bicycle) }\end{array}$} \\
\hline & $\begin{array}{l}\text { Strong references made by informants to the } \\
\text { development of their conceptual knowledge, and } \\
\text { application of these principled understandings to a }\end{array}$ & & \\
\hline & $\begin{array}{l}\text { range of manual tasks both in and outside the } \\
\text { workplace }\end{array}$ & & $\begin{array}{l}\text { "I watch...everyone now, even in the supermarket, to see if they [apply } \\
\text { manual handling concepts] to push their trolleys, get their groceries off } \\
\text { the shelves and unload them at the checkout" (Mike, trainee) }\end{array}$ \\
\hline
\end{tabular}


The account in Table 2 demonstrates that rather than moving from propositional to procedural capacities as suggested in some cognitive accounts (e.g., Anderson, 1982; Fitts \& Posner, 1967), these workers developed procedural capacities first, by rehearsing key manual handling tasks (i.e., pushing a wheelchair, using a hoist) in the classroom. After a period of time working in clients' homes, these HCWs had then rendered this procedural knowledge into a principled understanding of manual handling, and then adapted this new knowledge to become skilful in a range of other manual handling tasks (e.g., successfully preventing a client from falling out of their wheelchair, riding a bicycle, performing domestic duties). This principled understanding appears also to be person-dependent. Once these workers initially learn manual handling knowledge and skills in the classroom, their personal histories and accumulation of individual care work experiences over time shapes the further development of this knowledge and skills in the workplace (Billett, 2010; Collin, 2004). So, this development is a consequence and extension of their learning, in so far as it assists workers to identify what they know, do and value in terms of manual handling skills development.

\section{Discussion}

HCWs of this inquiry personally mediated their manual handling skills development, following a pathway that differs from traditional accounts (e.g., Anderson, 1982; Fitts \& Posner, 1967). Many of these workers enter clients' private homes as one of Cornford's (1996) novices, yet as they work with minimal professional supervision or guidance they are expected to very quickly become experts. This is a very ambitious expectation, although according to the findings of this inquiry, and Cornford (1996), not altogether unattainable. On the other hand, Cornford and Beven (1999) suggest that leaving novice learners to learn their occupational practices in a complex work environment without guidance is more likely to result in confusion and misunderstandings. Moreover, Stevenson (1994) states that to simply 
make knowledge available (e.g., in classroom training sessions) to learners is insufficient. Instead, relevance needs to be clearly identifiable by accessing what is already known and linking this to new knowledge.

To reiterate findings presented in Table 1 , all HCW informants of this inquiry demonstrated manual handling proficiency at 4 and 12 weeks post initial classroom training. Consequently, both curriculum (i.e., ordering of experiences) and pedagogies (i.e., how these experiences can be enriched) appear to be significant in facilitating skills development in their socially-isolated workplaces. The curriculum and pedagogies are now summarised in Table 3. The left-hand column reiterates each of the four phases of the 12-week training trajectory. The centre column outlines the key experiences of each phase and the right-hand column proposes intended outcomes for the worker as they move through each phase. 
Table 3. Curriculum and Pedagogies for Supporting Skills Development in Relative Social Isolation

\begin{tabular}{|c|c|c|}
\hline Phase & Key experiences & Intended outcomes for worker \\
\hline $\begin{array}{l}\text { One: } 0 \text { weeks } \\
\text { Initial classroom training }\end{array}$ & $\begin{array}{l}\text { Facilitated by highly experienced and skilled } \\
\text { educator } \\
\text { Introductions and discussion of personal } \\
\text { histories, motivations for taking up the HCW } \\
\text { role } \\
\text { Outline and clarification of role } \\
\text { Introduction of concepts, including body } \\
\text { awareness } \\
\text { Practise one or two routine manual handling } \\
\text { tasks in small groups }\end{array}$ & $\begin{array}{l}\text { Increased understanding of importance of HCW role and the degree of } \\
\text { professionalism required to undertake it } \\
\text { Heightened awareness of own body and understanding of the importance of } \\
\text { keeping the body safe } \\
\text { Some automation of routine manual tasks } \\
\text { Development of haptic capacity (i.e., 'getting a feel for' the work) } \\
\text { Linking of new manual handling knowledge and skills to what is already known } \\
\text { through personal histories, cultural and situational experiences }\end{array}$ \\
\hline $\begin{array}{l}\text { Two: } \mathbf{0}-\mathbf{8} \text { weeks } \\
\text { Working independently } \\
\text { in clients' homes but } \\
\text { with access to 'more } \\
\text { skilful others' and other } \\
\text { learning supports }\end{array}$ & $\begin{array}{l}\text { Working initially alongside and then with } \\
\text { direct access to experienced support worker } \\
\text { (preceptor) } \\
\text { Opportunities provided to observe, model and } \\
\text { engage in a range of manual tasks in clients' } \\
\text { homes }\end{array}$ & $\begin{array}{l}\text { Further development of foundational concepts } \\
\text { Increased automation of some tasks } \\
\text { Some tasks performed concurrently } \\
\text { Continued development of haptic capacity } \\
\text { Continued development of disposition for support role }\end{array}$ \\
\hline $\begin{array}{l}\text { Four: } 8 \text { weeks and } \\
\text { beyond } \\
\text { Working independently } \\
\text { with access to learning } \\
\text { supports as required }\end{array}$ & $\begin{array}{l}\text { Working independently in clients' homes } \\
\text { Access to experienced worker (preceptor) if } \\
\text { required }\end{array}$ & $\begin{array}{l}\text { Deepening development of conceptual knowledge } \\
\text { Increased efficiency in performing procedures with reduced need to consciously } \\
\text { retrieve conceptual knowledge } \\
\text { Evidence of ability to adapt to a range of complex workplace situations } \\
\text { Body health and safety prioritised } \\
\text { Autonomy of the workplace embraced } \\
\text { Range of learning supports accessed as required } \\
\text { Rich learning outcomes }\end{array}$ \\
\hline
\end{tabular}


The left-hand column in Table 3 clearly presents the curriculum which supported HCWs' skills development. In addition to the ordering of the experiences, however, information presented in this table also suggests that the classroom training format and provision of opportunities for engagement and sharing are also important in developing skills in situations of relative social isolation.

Although the brevity of classroom orientation sessions may have perceived limitations (Aylward et al., 2003; Baldock \& Mulligan, 2000; Bernoth, 2009), there may also be advantages here, in that short initial classroom training interludes are not overwhelming for new workers. HCWs bring to the classroom a range of previous educational experiences and potential apprehensions about commencing in their new role. Hence, brief classroom training sessions that convey basic concepts and procedures, provide opportunities to apply these in a highly practical training session and encourage interaction with peers, may also assist in the formation of a positive disposition for the role. This experience, in turn, can facilitate skills development in relative social isolation, as workers who are encouraged to develop a disposition for their role in the classroom may also exercise their agency when working in the privacy of their clients' homes (Billett, 2010; Collin, Paloniemi, Virtanen \& Eteläpelto, 2008; Eteläpelto et al., 2013).

Refresher classroom training after a period of time in their occupational role may also further facilitate skills development for individuals who work without direct supervision and support. The format of these refresher training sessions appears to be particularly significant here. The presentation, discussion and solving of authentic (i.e., selected by the workers themselves) manual handling problems through practice was found to further develop foundational concepts and also encourage workers to move beyond replication of routine tasks. The group work and interaction in these sessions means that for each manual handling scenario, a broader range of solutions may be offered than those that can be scoped by 
individuals alone. So, when faced with non-routine problems when working in isolation, these workers may be able to recall from their classroom refresher training how solutions were effected. This strategy may be helpful in enhancing skills development in relative social isolation.

The experiences recounted here support the provision of opportunities for engagement and sharing for workers who are required to demonstrate skilfulness in socially-isolated circumstances. These experiences are reminiscent of Orr's (1990) 'war stories' - i.e., workers discussing work-related issues as they gather around water coolers, during lunch breaks or at social meetings leads easily to a shared understanding and creation of new knowledge. Similarly, Billett (2011) suggests that learning is enhanced by affording opportunities for workers to participate in 'dialogue forums', sharing their knowledge and hearing from others at the same time, without positioning themselves in a teacher-student relationship. Liveng (2010), too, considers that in the health care sector, supervision groups, network groups and interdisciplinary conferences constitute valuable learning settings in which individuals and groups of workers are able to develop their skilfulness. In these settings, professional knowledge is shared and exchanged while at the same time promoting a sense of teamwork, collegiality and affording an opportunity for workers to make normative comparisons with their peers (Cantillon, 2016; Liveng, 2010). These (and other) kinds of peer interaction may also reduce feelings of professional isolation, maintain cognitive ability, improve morale and lead to better workplace practices (Cantillon, 2016).

This organised, shared, practical understanding suggested for skills development is suggestive of Gherardi's (2009) 'practice of community'. She suggests that this practice is not necessarily an autonomous body of propositions, but is more ill-defined, where new identities and modes for action are continuously formed through negotiations with the social world. So for HCWs who practice in clients' private homes, the opportunities provided for 
them to engage in the practice of community, i.e., share knowledge and understanding with others in the classroom training sessions, may have assisted them to shift interchangeably between their procedural and conceptual knowledge, and develop their skillfulness.

\section{Conclusion}

In conclusion, this paper proposes that manual handling skills development for HCWs who conduct their practice in relative social isolation is personally unique. In contrast to traditional accounts, these workers developed procedural capacities first, rendered these capacities into conceptual understandings, and then adapted these understandings to become skillful in a range of other tasks. Moreover, these workers placed high value on sociality in developing their skills. Consequently, a training format which focuses on the development of procedural knowledge, and provides opportunities for shared practice, is most important for learning in circumstances of relative social isolation.

\section{References}

Anderson, J. R. (1982). Acquisition of cognitive skill. Psychological Review, 89(4), 369-406.

Anderson, J. R. (1993). Problem solving and learning. American Psychologist, 48, 35-44. Australian Institute of Health and Welfare. (2013). Australia's welfare 2013 (Cat. no. AUS 174). Canberra: AIHW.

Australian Skills Training Authority. (2013). Report: Training for aged and community care in Australia. Canberra: Australian Government

Aylward, S., Stolee, P., Keat, N., \& Johncox, V. (2003). Effectiveness of continuing education in long-term care: A literature review. The Gerontologist, 43(2), 259-271.

Baldock, C., \& Mulligan, D. (2000). Restructuring and women workers in Australian home care. Resources for Feminist Research, 27(3/4), 13-27.

Benner, P. (2004). Using the Dreyfus model of skill acquisition to describe and interpret skill acquisition and clinical judgement in nursing practice and education. Bulletin of Science Technology Society, 24(3), 188-199. 
Bernoth, M. (2009). '... and the word was made flesh' - The impact of discourses of embodiment in promoting safe manual handling practice in aged care (Doctoral Dissertation, Monash University, Victoria, Australia).

Billett, S. (2001). Learning in the workplace: Strategies for effective practice. NSW, Australia: Allen \& Unwin.

Billett, S. (2010). Learning in and for working life: A relational interdependence between personal and social agency. In M. Van Woerkom \& R. Poell (Eds.), Workplace learning: Concepts, measurement and application (pp. 11-26). USA: Routledge.

Billett, S. (2011). Promoting lifelong employability for workforce aged over 45: Singaporean workers' perspectives. International Journal of Continuing Education and Lifelong Learning, 3(2), 57-73.

Billett, S. (2013). Recasting transfer as a socio-personal process of adaptable learning. Educational Research Review, 8, 5-13.

Blaikie, N. (2009). Designing social research. UK: Polity.

Bogdan, R. C., \& Biklen, S. K. (2007). Research for education: An introduction to theories and methods. New York: Pearson.

Brown, J. S., Collins, A., \& Duguid, P. (1989). Situated cognition and the culture of learning. Educational Researcher, 18(1), 32-34.

Cantillon, P. (2016). Learning at the frontier: The experiences of single-handed general practitioners. In Billett, S., Dymock, D., \& Choy, S. (Eds.). Supporting Learning Across Working Life: Models, Processes and Practices (Vol. 16). Switzerland: Springer.

Cobb, P. (1998). Learning from distributed theories of intelligence. Mind, Culture, and Activity, 5, 187-204.

Collin, K. (2004). The role of experience in work and learning among design engineers. International Journal of Training and Development, 8(2), 111-127.

Collin, K., Paloniemi, S., Virtanen, A., \& Eteläpelto, A. (2008). Constraints and challenges on learning and construction of identities at work. Vocations and Learning, 1(3), 191210.

Cornford, I. R. (1996). The defining attributes of 'skill' and 'skilled performance': Some implications for training, learning and program development. Australian and New Zealand Journal of Vocational Education Research, 4(2), 1-25. 
Cornford, I. R., \& Beven, F. A. (1999). Workplace learning: Differential learning needs of novice and more experienced workers. Australian and New Zealand Journal of Vocational Education Research, 7(2), 25-54.

Ericsson, K. A. (2004). Deliberate practice and the acquisition and maintenance of expert performance in medicine and related domains. Academic Medicine, 79(10), S70-S81.

Eteläpelto, A., Vähäsantanen, K., Hökkä, P., \& Paloniemi, S. (2013). What is agency? Conceptualizing professional agency at work. Educational Research Review, 10, 4565.

Faucett, J., Kang, T., \& Newcomer, R. (2013). Personal service assistance: Musculoskeletal disorders and injuries in consumer-directed home care. American Journal of Industrial Medicine, 56, 454-468.

Fitts, P.M., \& Posner, M.I. (1967). Human Performance. Oxford: Brooks/Cole.

Fosnot, C. T. (2013). Constructivism: Theory, perspectives, and practice. New York: Teachers College Press.

Gergen, K. J. (1994). Realities and relationships: Soundings in social construction. Cambridge, Mass: Harvard University Press.

Gherardi, S. (2009). Community of practice or practices of a community? In S. Armstrong \& C. Fukami (Eds.), The Sage handbook of management learning, education, and development (pp. 514-530). London: Sage.

Glaser, R. (1984). Education and thinking - the role of knowledge. American Psychologist, 39(2), 93-104.

Goodnow, J. J. (1990). The socialisation of cognition: What's involved? In J. W. Stigler, R. A. Shweder, \& G. Herdt (Eds.), Cultural psychology (pp. 259-286). Cambridge, England: Cambridge University Press.

Health and Community Services Workforce Council. (2012, June). Industry overview: Industry skills and workforce development report for the health and community services industry. Brisbane: Health and Community Services Workforce Council Inc.

Hughes, J., Jewson, N., \& Unwin, L. (Eds.). (2013). Communities of practice: Critical perspectives. London: Routledge.

Keleher, H. (2003). Community care in Australia. Home Health Care Management and Practice, 15(5), 367-374.

Lave, J., \& Wenger, E. (1991). Situated learning: Legitimate peripheral participation. Cambridge: Cambridge University Press. 
LeCompte, M. D., \& Goetz, J. P. (1982). Problems of reliability and validity in ethnographic research. Review of educational research, 52(1), 31-60.

Liveng, A. (2010). Learning and recognition in health and care work: An inter-subjective perspective. Journal of Workplace Learning, 22(1-2), 41-52.

Markannen, P., Quinn, M., Galligan, C., Sama, S., Brouillette, N., \& O’Keyer, D. (2014). Characterising the nature of home care work and occupational hazards: A developmental study. American Journal of Industrial Medicine, 57, 445-457.

Martin, B., \& Healy, J. (2010, August). Who works in community services? (Report of research funded by the Community and Disability Services Ministers Advisory Council, directed by its Structural Issues in the Workforce Subcommittee). Flinders University, Adelaide, Australia: National Institute of Labour Studies.

Merriam, S. B. (2014). Qualitative research: A guide to design and implementation. San Francisco, CA: John Wiley \& Sons.

Mott, S., Chau, A., \& Chan, J. (2007). Meeting the health needs of people with disability living in the community. Journal of Intellectual and Developmental Disability, 32(1), $51-53$.

Nursing home found in breach of act over accident with a hoist. (2008, July 9). Aged Care Crisis. Retrieved from http://www.agedcarecrisis.com/index.php/news/68media/2965-nursing-home-found-in-breach-of-act-over-accident-with-a-hoist

Orr, J. (1990). Sharing knowledge, celebrating identity: War stories and community memory in a service culture. In D. S. Middleton \& D. Edwards., (Eds.), Collective remembering: Memory in society (pp. 169-189). Newbury Park: Sage.

Palesy, D. (2015). 'Learning occupational practice in the absence of expert guidance: A case study of in-home disability support workers' (Doctoral Dissertation, Griffith University, Queensland, Australia).

Palesy, D. (2016). Home health aide training: An appeal for organisational support. Home Health Care Now, 34, (7), 381-387

Radford, K., Shacklock, K., \& Bradley, G. (2015). Personal care workers in Australian aged care: retention and turnover intentions. Journal of nursing management, 23(5), 557566.

Rogoff, B., \& Lave, J. (Eds). (1984). Everyday cognition: Its development in social context. Cambridge, USA: Harvard University Press.

Ryle, G. (1949). The concept of mind. London: Hutchinson University Library. 
Salomon, G. (1997). Distributed cognitions: Psychological and educational considerations. Cambridge, England: Cambridge University Press.

Stenhouse, L. (1988). Case study methods. In J. P. Keeves (Ed.), Educational research, methodology and measurement: An international handbook (pp. 49-53). Oxford: Pergamon.

Stevenson, J. C. (1994). Vocational expertise. In J. C. Stevenson (Ed.), Cognition at work: The development of vocational expertise (pp. 7-35). Adelaide, South Australia: National Centre for Vocational Education Research.

Stone, R., Sutton, J., Bryant, N., Adams, A., \& Squillace, M. (2013). The home health workforce, a distinction between worker categories. Home Health Services Quarterly, $32(4), 218-233$.

Tenison, C., Fincham J., \& Anderson, J. (2016). Phases of learning: How skills acquisition impacts cognitive processing. Cognitive Psychology, 87, 1-28.

Thomas, D. (2006). A general inductive approach for analysing qualitative evaluation data. American Journal of Evaluation, 27(3), 237-246.

Tuohy-Main, K. (1997, August). Prevention of manual handling injuries to residents in aged care. Paper presented at International Gerontology Congress, Adelaide, Australia.

Valsiner, J. (1994). Bi-directional cultural transmission and constructive sociogenesis. In W. de Graaf \& R. Maier (Eds.), Sociogenesis re-examined (pp. 47-70). New York: Springer.

Valsiner, J. (2000). Culture and human development. London: Sage.

Varcin-Coad, L. (2003). Manual handling for carers of people : Freestyle technique \& sit to stand : video booklet including competency based assessment tools. Gold Coast, Queensland: Varcin \& Associates.

Von Glasersfeld, E. (1984). An introduction to radical constructivism. In P. Watzlawick (Ed.), The invented reality (pp. 17-40). New York: Norton.

Vygotsky, L.S. (1978). Mind in society: The development of higher psychological processes. Cambridge: Harvard University Press.

Wiersma, W. (2009). Research methods in education. New Delhi: Pearson Education India.

Wilkesmann, M., \& Wilkesmann, U. (2011). Knowledge transfer as interaction between experts and novices supported by technology. Vine, 41(2), 96-112.

Yin R, K. (2009). Case Study Research: Design and Methods. 4th ed. Thousand Oaks, CA: Sage. 